\title{
Deformação neógena e suas implicações na estruturação dos campos de petróleo na região de Icapuí-Ponta Grossa (CE), Bacia Potiguar emersa
}

\author{
Debora do Carmo Sousa ${ }^{1}$, Emanuel Ferraz Jardim de Sá ${ }^{2} \&$ Alex Francisco Antunes ${ }^{2}$
}

\begin{abstract}
Resumo Em falésias costeiras no extremo oeste da Bacia Potiguar (Plataforma de Aracati), a Formação Barreiras, de idade miocênica, exibe estruturas que caracterizam uma deformação de expressiva magnitude. $\mathrm{O}$ levantamento em detalhe da geometria das falhas e dobras que afetam a Formação Barreiras conduziu ao reconhecimento de estruturas distensionais (na localidade Ponta Grossa) e oblíquas contracionais (localidade Vila Nova, próxima a Icapuí), associadas a um sistema de transcorrências com direções NE (nestas localidades) e NW (Falha de Afonso Bezerra, na porção central da bacia). Os dados obtidos permitem caracterizar um campo de tensões de idade neógena, que gerou falhas, dobras e estruturas hidroplásticas, incluindo trama SL e zonas de cisalhamento, e reativou estruturas mais antigas, presentes na seção sedimentar neocretácea, subjacente. A reinterpretação de seções sísmicas desta região e outros dados geológicos em várias localidades da Bacia Potiguar, permitiram delinear estruturas correlatas (em estilo e regime cinemático) afetando as rochas siliciclásticas da Formação Açu e carbonáticas da Formação Jandaíra, bem como basaltos da Formação Macau, cuja idade situa-se no limite Oligoceno-Mioceno. O reconhecimento desse arcabouço estrutural demanda compatibilizar a deformação em superfície com aquela observada nas seções sísmicas, que inclui pulsos/eventos cuja idade pode ser mais antiga (intervalo Neocretáceo a Paleógeno). Este modelo traz implicações importantes para a estruturação (geometria, cinemática, idade de trapas) dos reservatórios de petróleo (especialmente os arenitos da Formação Açu, no Campo de Fazenda Belém) e dos processos de migração e armadilhamento de hidrocarbonetos neste setor da Bacia Potiguar.
\end{abstract}

Palavras-chave: Bacia Potiguar, Neógeno, Formação Barreiras, campos de petróleo, Fazenda Belém.

\begin{abstract}
Neogene deformation and its implications for the structural framework of the oil fields in the Icapui-Ponta Grossa (CE) region, onshore Potiguar Basin. In coastal cliffs at the western portion of the Potiguar Basin (so-called Aracati Platform), the Barreiras Formation, of miocene age, displays structures pointing to high strain deformation. Detailed mapping of faults and folds geometry in the Barreiras Formation leds to recognition of extensional structures (at Ponta Grossa village) and contractional oblique structures (Vila Nova, next to Icapuí town), both of them related to a transcurrent system bearing NE (at these locations) and NW trends (Afonso Bezerra Fault, in the central portion of the basin). These data point to a neogene stress field which generated faults, folds and hydroplastics structures, including SL fabrics and shear zones, as well as reactivated older structures in the underlying neocretaceus sedimentary section. Reinterpretation of seismic sections from this region and other geological data at several places in the Potiguar Basin outline structures which are correlated (in style and kinematic regime) throughout the siliciclastic rocks of the Açu Formation, limestones of the Jandaíra Formation and younger basalts of the Macau Formation, whose age straddles the Oligocene-Miocene boundary. This structural framework recognized at the surface has to be compatible with subsurface deformation as observed in seismic sections, which includes pulses/events of older, Neocretaceus to Paleogene age. This model has important implications as regards the structure (geometry, kinematics, age op traps) of oil reservoirs (especially the sandstones of the Açu Formation, in the Fazenda Belém Oil Field) and the processes of migration and hydrocarbon entrapment at this region of the Potiguar Basin.
\end{abstract}

Keywords: Potiguar Basin, Neogene, Barreiras Formation, oil fields, Fazenda Belém.

INTRODUÇÃO Uma melhor compreensão da evolução tectônica da Bacia Potiguar constitui um ponto extremamente importante para formular um modelo para a Margem Equatorial Brasileira. A estruturação principal da bacia é de idade eocretácea, sendo conhecida princi- palmente a partir de dados sísmicos ou sondagens. Por outro lado, estão se acumulando evidências de estruturas cenozóicas e reativações neotectônicas impressas nos litotipos aflorantes de idade pós-aptiana, na referida bacia (Caldas et al. 1997, Dantas 1998, Bezerra et al.

1- Programa de Pós-Graduação em Geodinâmica e Geofísica, Departamento de Geologia e PRH22/ANP, UFRN. Natal (RN), Brasil.

E-mail: debora@geologia.ufrn.br

2 - Departamento de Geologia e PRH22/ANP, UFRN, Natal (RN), Brasil 
1998, Jardim de Sá et al. 1999, Sousa et al. 1999, 2001), inclusive com reflexo importante em subsuperfície. Os trabalhos citados documentam feições deformacionais expressivas, penecontemporâneas ao importante marco estratigráfico que é a Formação Barreiras.

O controle estrutural envolvido na acumulação de hidrocarbonetos é inferido, na maioria das vezes, por métodos indiretos (sísmica) e amostras restritas (testemunhos e calhas). São comparativamente raras as oportunidades de conhecer e detalhar estruturas controladoras de hidrocarbonetos em afloramentos que possibilitam uma visão 3D. Na Bacia Potiguar, a migração e acumulação de hidrocarbonetos constituem um processo relativamente jovem, do Neógeno. Os marcadores deste evento, aflorando no continente, incluem rochas sedimentares cretáceas, pós-aptianas, e as formações Tibau e Barreiras, além de coberturas mais jovens. Detalhar a estratigrafia e a estrutura desses depósitos contribui para melhorar o conhecimento da seção de interesse econômico na bacia, no que se refere à exploração e explotação de petróleo na sua porção onshore e offshore rasa.

Os dados e resultados apresentados neste artigo são de interesse para a caracterização de reservatórios como os do Campo de Fazenda Belém, vizinho à área de trabalho detalhado no litoral. Adicionalmente, o modelo estrutural definido tem implicações importantes para o condicionamento de hidrocarbonetos em vários outros campos situados tanto na Bacia Potiguar quanto na Bacia do Ceará.

O entendimento da evolução estrutural desta região da margem continental, a partir das feições identificadas nas unidades mais rasas/mais jovens da Bacia Potiguar, proporcionará uma melhor compreensão sobre a estruturação em profundidade, em especial na seção neocretácea-terciária, de maior interesse para a exploração de hidrocarbonetos na bacia. Este tipo de dado pode subsidiar inferências sobre a migração e acumulação de hidrocarbonetos, com aplicação potencial a campos como o de Fazenda Belém, que está situado no prolongamento para $\mathrm{S} / \mathrm{SW}$ da área estudada.

\section{LOCALIZAÇ̃̃O DA ÁREA E CONTEXTO GEO-}

\section{LÓGICO REGIONAL A área localiza-se na porção} oeste da Bacia Potiguar, entre as localidades de Lagoa do Mato e Icapuí, litoral oriental do Estado do Ceará (Fig. 1).

Geologicamente, esta área está situada na "Plataforma de Aracati”, na qual a seção sedimentar pósaptiana capeia uma extensa área do embasamento cristalino. Os mapas geológicos, seções sísmicas e mapas gravimétricos residuais identificam altos do embasamento, considerados feições paleogeomórficas, alinhados na direção NE-SW. O embasamento é recoberto por cerca de $400 \mathrm{~m}$ de arenitos fluviais albo-cenomanianos da Formação Açu. O registro de uma extensa plataforma carbonática, de idade turoniana-neocampaniana, é representada pela Formação Jandaíra, com cerca de $250 \mathrm{~m}$ de espessura nesta área, de acordo com dados de subsuperfície da PETROBRAS. Recobrindo estas litologias, ocorrem rochas siliciclásticas relacionadas à
Formação Barreiras, além de sedimentos informalmente denominados de "pós-Barreiras".

LITOESTRATIGRAFIA DA ÁREA Na região compreendida entre Icapuí e Lagoa do Mato, as litologias aflorantes são individualizadas em dois conjuntos: i) uma unidade carbonática, que ocorre de forma restrita, na base das falésias, e ii) unidades siliciclásticas, que predominam lateral e verticalmente, ao longo das falésias. O cenário de ocorrência destes dois conjuntos pode ser observado nas figuras 1 e 2 .

As rochas carbonáticas correlatas à Formação Jandaíra afloram na base das falésias (Fig. 3), sob a forma de pequenos lajedos ao nível da praia atual, em geral recobertos pelas areias de praia na maior parte do ano. Esses afloramentos são compostos por calcários maciços, localmente fossilíferos, constituindo fácies de packstones a wackestones bioclásticos, depositadas em ambiente lagunar com contribuição fluvial.

As rochas da Formação Barreiras ocorrem sob a forma usual de estratos horizontalizados e não-deformados, ou como camadas basculadas e afetadas por deformação de forte magnitude (acamamento e falhas com forte basculamento), em um trecho mais restrito do litoral a oeste de Icapuí (Sousa 2003). Nos trechos nãodeformados, as falésias expõem principalmente o nível superior (fácies superior) da Formação Barreiras (Fig. 3 ), o qual é composto por arenitos médios a grossos, com intercalações conglomeráticas de coloração avermelhada, geralmente apresentando estrutura maciça. Localmente (W de Ponta Grossa), algumas falésias exibem o nível inferior da Formação Barreiras, sobreposta aos carbonatos da Formação Jandaíra. Todavia, é nas falésias com rochas deformadas (basculadas) que a fácies inferior da Formação Barreiras está mais bem exposto, sendo representado por arenitos médios a finos, com coloração variando entre amarelo, roxo e vermelho, em alguns casos mostrando-se bastante oxidados.

As rochas correlatas à Formação Tibau afloram no extremo oeste da área, entre as localidades de Lagoa do Mato e Sítio Retirinho (Fig. 3). Caracterizam-se por arenitos médios a grossos, por vezes sem estrutura interna aparente, com coloração amarelada a esverdeada, contendo níveis de argila, possíveis marcas de raízes e grânulos de quartzo dispersos. As rochas desta unidade transicionam lateralmente para os litotipos da Formação Barreiras.

Capeando discordantemente a porção superior das rochas das formações Barreiras e Tibau (Fig. 3), ocorrem sedimentos que representam paleodunas e que podem ser correlacionados à Formação Potengi, presente em várias localidades no Estado do Rio Grande do Norte. Tais sedimentos são caracterizados por areias de coloração branca, amarela ou vermelha, relacionadas à sedimentação eólica. Mais comumente, o contato inferior dos litotipos da Formação Potengi com as rochas da Formação Barreiras se dá de forma erosional (marcado pela diferença no grau de litificação dos sedimentos), tornando-se mais nítido quando os estratos sotopostos encontram-se basculados e falhados, caracterizando uma discordância angular. 


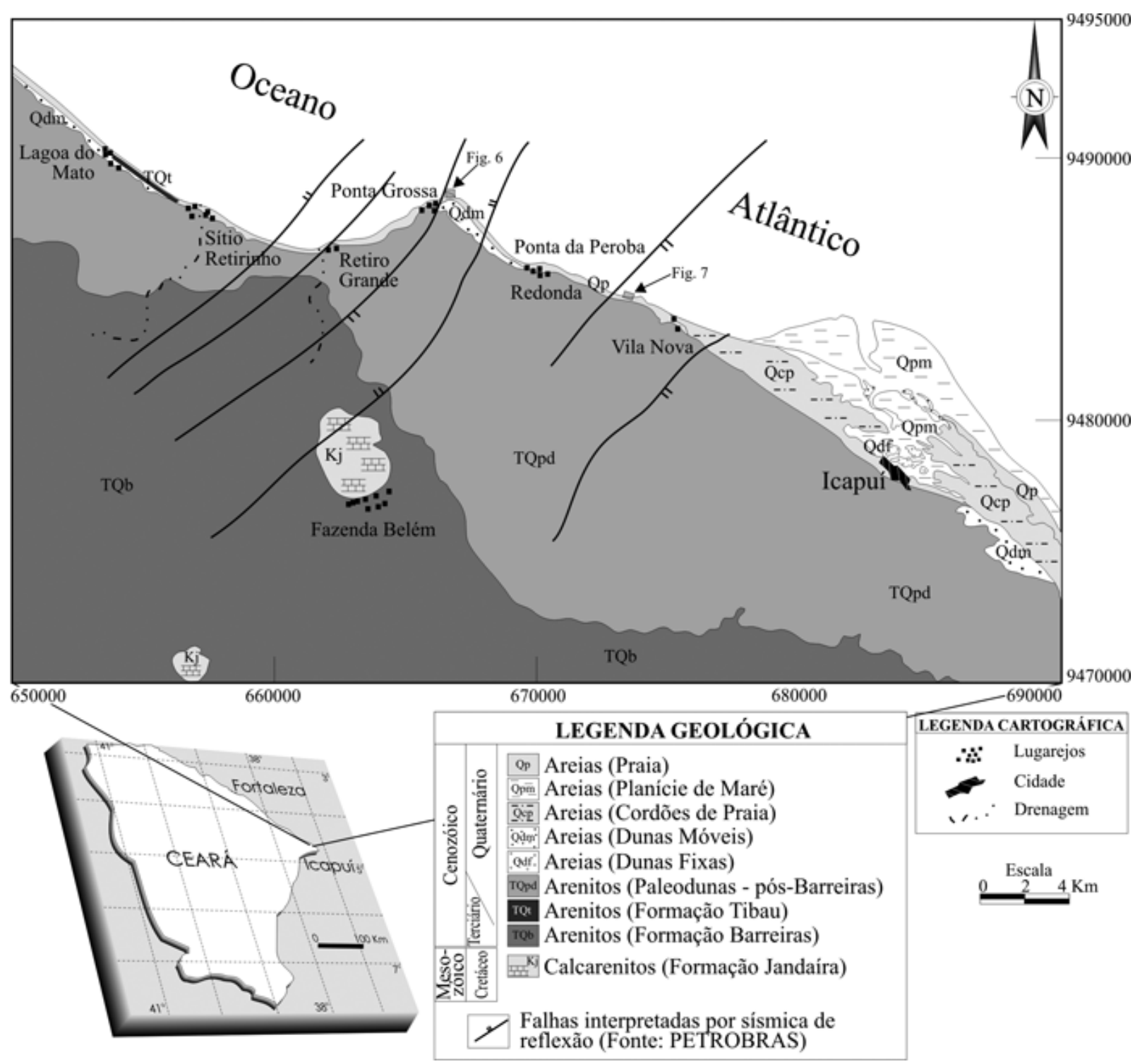

Figura 1 - Mapa geológico simplificado da região litorânea de Icapuí/CE.

A DEFORMAÇÃO NA FORMAÇÃO BARREIRAS Na área estudada, destaca-se uma forte estruturação impressa nas rochas da Formação Barreiras. Este tipo de feição, ainda pouco conhecida em depósitos tão jovens (idade neógena a pleistocênica), foi descrito em alguns trabalhos pioneiros e atestam a ocorrência de eventos neotectônicos na região Nordeste (Bezerra \& Vita-Finzi 2000, Jardim de Sá et al. 1999, Jardim de Sá 2001, Bezerra et al. 2006, Nogueira et al. 2006, Furrier et al. 2006, Lima et al. 2006).

Zonação estrutural ao longo do litoral Uma zonação das feições estruturais desde as bordas até o núcleo de várias zonas de falhas, é identificada ao longo das falésias costeiras, em um perfil de direção NW-SE com cerca de $60 \mathrm{~km}$ de extensão, partindo da localidade de Lagoa do Mato passando por Ponta Grossa e Vila Nova, no Ceará, até a Praia de Tibau, já no Rio Grande do Norte:

(a) Desde a localidade de Lagoa do Mato até o Sítio Retirinho, as formações Tibau e Potengi são caracterizadas por estratos horizontalizados, não-deformados. Neste caso, as falésias são compostas, na base, pelas rochas da Formação Tibau, capeadas pelos litotipos da Formação Potengi. Neste setor, a Formação Barreiras não aflora. Em direção ao povoado de Sítio Retirinho, ocorre uma passagem lateral entre as formações Barreiras e Tibau. Neste último povoado, a porção superior da Formação Barreiras, aflorante, exibe feições estruturais simples, na forma de diques neptunianos com direção N-S, preenchidos por arenitos conglomeráticos (Fig. 4);

(b) Algumas falhas, denunciadas por basculamento de estratos $\left(10^{\circ}\right.$ a $20^{\circ}$ para leste $)$ e dobras rollover, ocorrem em torno da localidade de Retiro Grande. Um nível laterítico e arenitos avermelhados no topo da Formação Barreiras são espessados em direção a uma das falhas (Fig. 5). Essa tectônica sindeposicional se atenua nos estratos da Formação Potengi, que preser- 
Deformação neógena e suas implicações na estruturação dos campos de petróleo na região de Icapui-Ponta Grossa (CE), Bacia Potiguar emersa

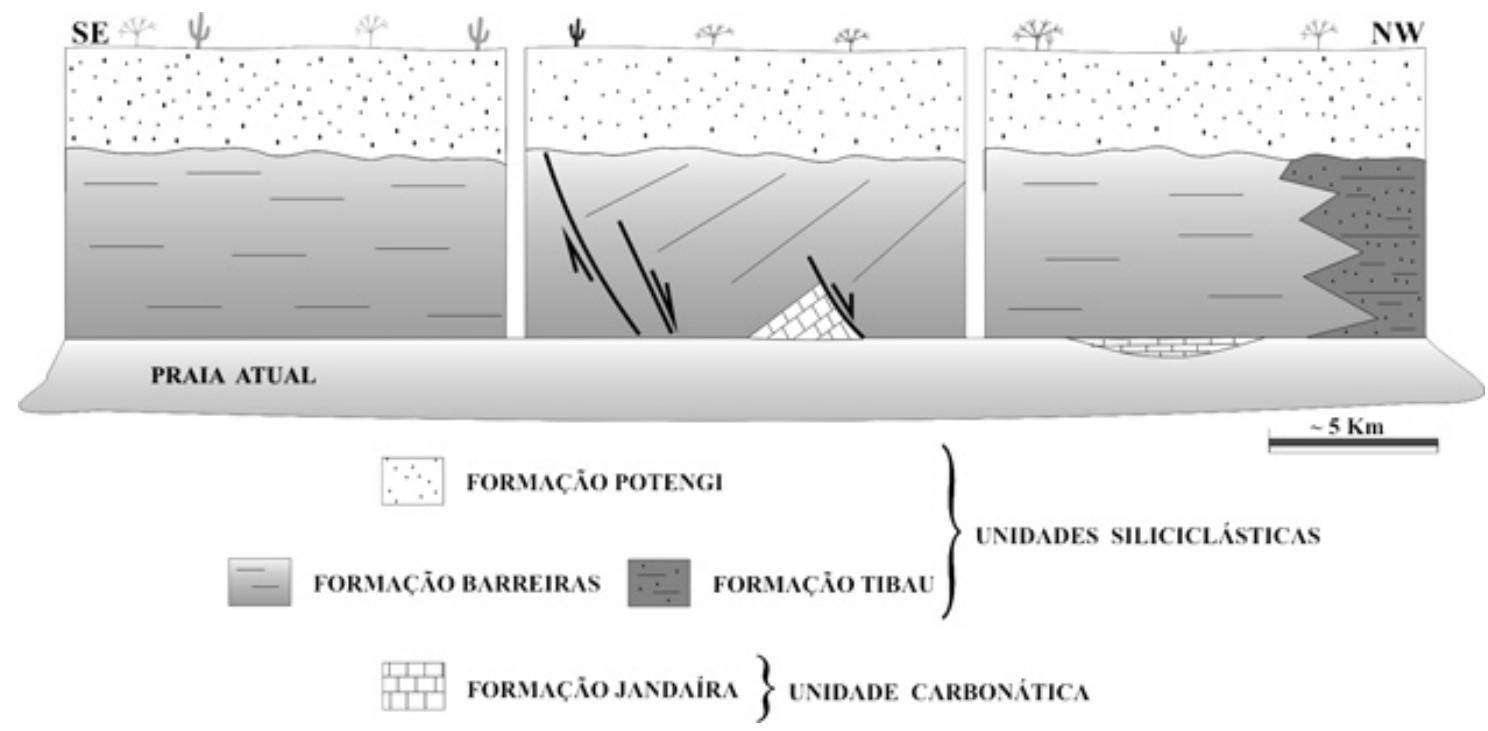

Figura 2 - Cenário esquemático de ocorrência das unidades carbonática e siliciclásticas encontradas ao longo das falésias costeiras entre Icapuí e Lagoa do Mato (Sousa 2003).
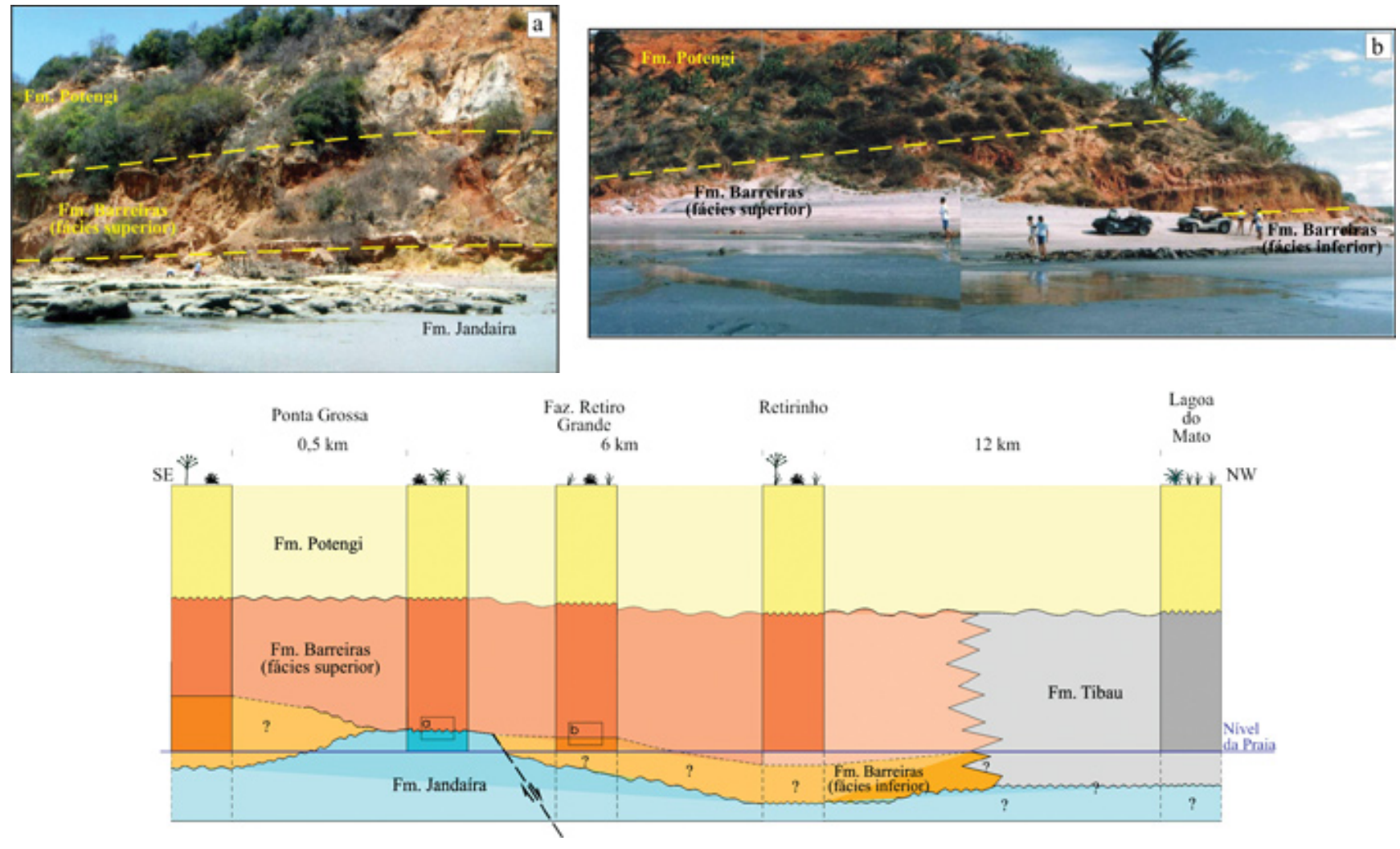

Figura 3 - Modo de ocorrência das rochas carbonáticas e siliciclásticas da região entre Ponta Grossa e Lagoa do Mato. Observar a distribuição lateral das fácies da Formação Barreiras entre essas localidades, ilustrando o possível controle tectônico-erosional na omissão da fácies inferior, no povoado de Ponta Grossa (a). Em direção a oeste, a fácies inferior volta a aparecer, restritamente, na sede da Fazenda Retiro Grande (b). Ver localidades na figura 1.

vam sua espessura ao longo desta e de outras seções intensamente deformadas. Próximo às falésias de Ponta Grossa, a SW, o calcário da Formação Jandaíra en- contra-se exposto sotoposto às rochas siliciclásticas da Formação Barreiras;

(c) Nas falésias de Ponta Grossa ocorre uma 


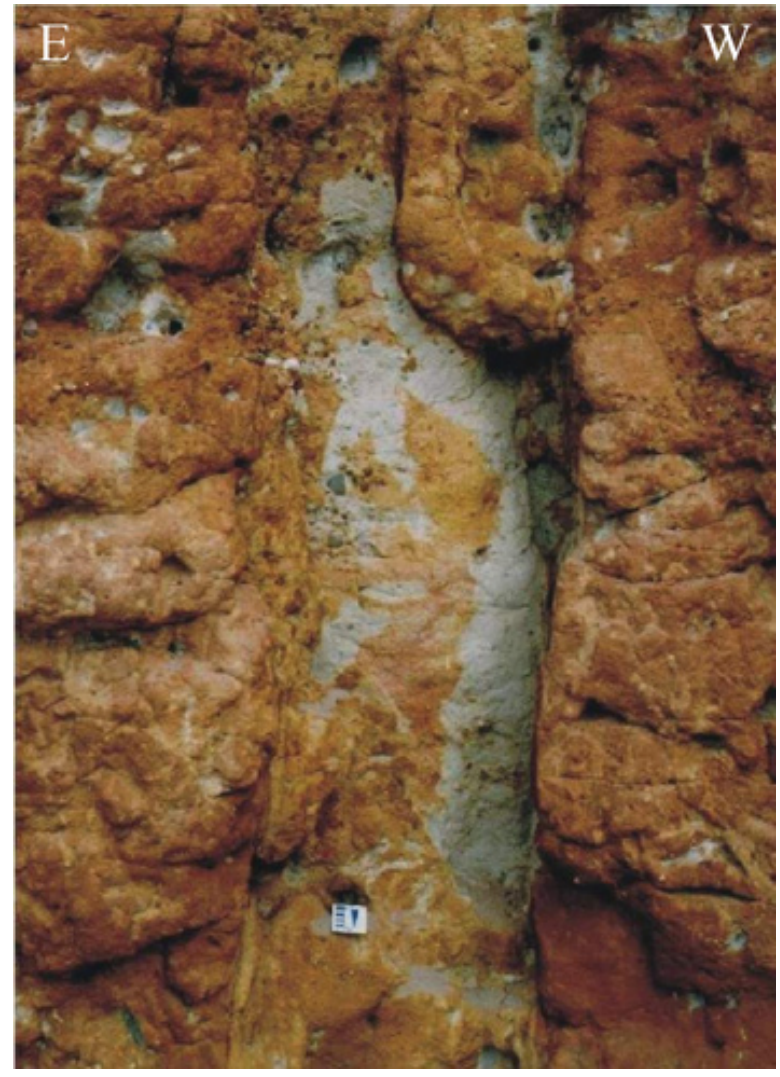

Figura 4 - Juntas N-S subverticais contolando um dique neptuniano, preenchido por arenitos conglomeráticos, na localidade de Sítio Retirinho.

zona de deformação intensa e complexa, com especial destaque para um sistema de falhas distensionais, onde fica evidente a discordância estrutural entre as formações Barreiras e Potengi. O calcário da Formação Jandaíra, tectonizado, aflora localmente, na base da falésia. Ao longo desta localidade, as feições estruturais são caracterizadas por falhas com direção N-S a NNE, bas- culamento e espessamento de camadas em direção às falhas, estruturas rollover, zonas de descolamento e falhas com estilo dominó, estruturação que é compatível com uma distensão E-W/WNW. Zonas de cisalhamento tardias (WNW-ESE), contendo estrias de alto rake e indicadores de movimento normal, apontam para um evento subseqüente de distensão N-S/NNE;

(d) A Formação Barreiras reaparece fortemente deformada em falésia imediatamente a leste do povoado de Redonda, novamente com feições de basculamento de camadas, fraturas e falhas de alto e de baixo ângulo, compatíveis com o mesmo sistema de deformação distensional presente em Ponta Grossa;

(e) Nas vizinhanças da Ponta da Peroba, a SE de Redonda, ocorre outra zona de forte deformação (ou a continuidade da anterior?) afetando a Formação Barreiras, novamente com falhas distensionais e de rejeito direcional. Um terceiro afloramento do calcário da Formação Jandaíra é condicionado por um bloco soerguido neste trecho;

(f) Continuando para leste/SE, segue-se uma nova série de falésias que expõem a Formação Barreiras, até a localidade de Vila Nova, a NW da sede municipal de Icapuí. Mais uma vez, as rochas estão afetadas por intensa deformação, porém com estilo contracional, cujas feições estruturais mais marcantes compreendem dobras suaves com linhas de charneira mergulhando para SSW, em alguns locais com planos incipientes de clivagem, afetando a seção inferior da Formação Barreiras. Estas feições denotam um campo de tensões envolvendo encurtamento E-W. A seção superior da Formação Barreiras invariavelmente ocorre delimitada por falhas. Concreções ferruginosas apresentam uma trama $\mathrm{L}>\mathrm{S}$, observado especialmente nas proximidades de planos de falhas;

(g) Após esta exposição em Vila Nova, as falésias só reaparecem na Praia de Tibau, já no litoral do Rio Grande do Norte, onde afloram rochas correlacionadas à Formação Tibau, capeadas pela Formação Potengi. Nes-

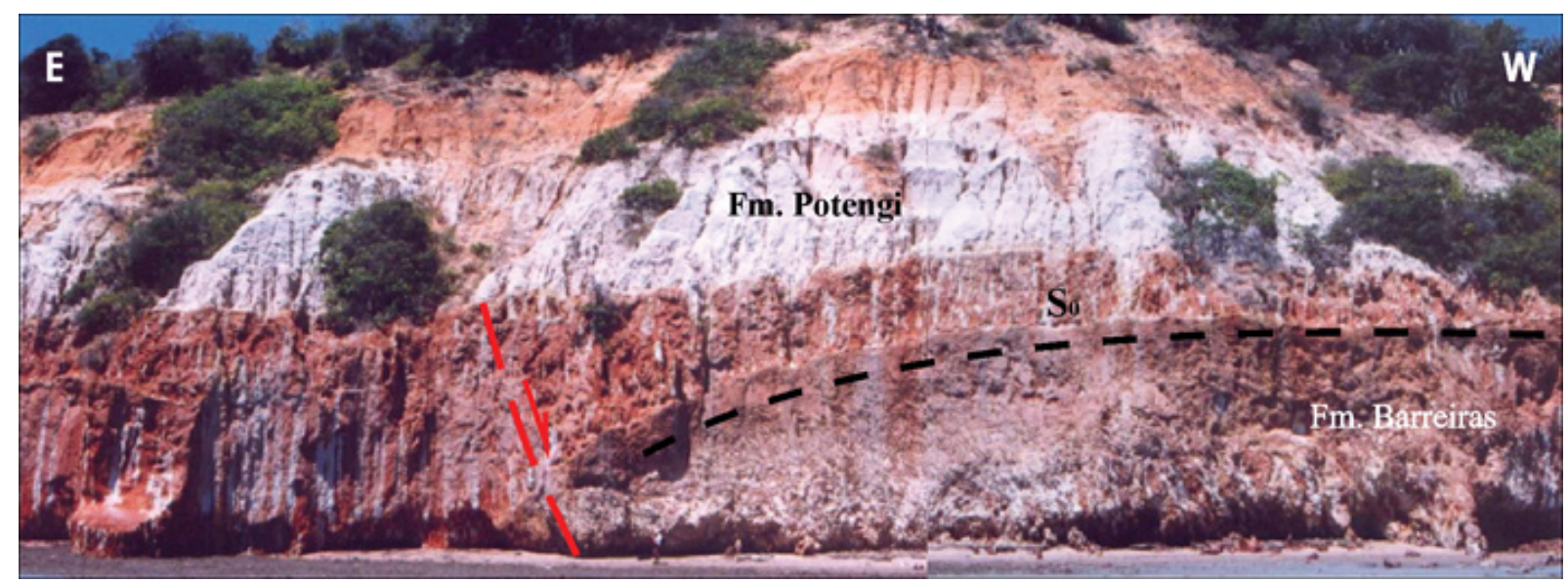

Figura 5 - Falha distensional com estrutura rollover associada, afetando a fácies superior da Formação Barreiras, na localidade de Retiro Grande. 
te local, os estratos encontram-se novamente horizontalizados, aparentemente pouco ou não deformados.

Estilo estrutural em superfície Considerando a região de Ponta Grossa, as feições em macroescala mais marcantes são falhas distensionais N-S a NNE, com mergulho variando de alto a baixo ângulo, preferencialmente para oeste. Os estratos encontram-se basculados em torno de $30^{\circ}$ a $40^{\circ}$ para leste. Onde expostas imediatamente a leste da vila (setor SW do corte na Fig. 6), observa-se que o basculamento é mais forte (até $50^{\circ}$ ) na seção (fácies) inferior da Formação Barreiras, sendo atenuado até o topo (correspondente à fácies superior). Juntas distensionais de alto ângulo, por vezes incipientemente sigmoidais, com direção N-S, cortam o acamamento. Na fácies superior da Formação Barreiras, foi possível observar o espessamento e basculamento das camadas para leste, incluindo uma camada de conglomerado lateritizado, próximo a uma falha principal N-S com mergulho para oeste, gerando uma estrutura rollover (Fig. 6). Tais feições estruturais podem ser compatibilizadas com uma distensão E-W, em parte sindeposicional à fácies superior da Formação Barreiras. Esta direção de distensão é a feição estrutural marcante na área, caracterizando o evento principal de deformação na região de Ponta Grossa.

No setor NE do corte na figura 6, o nível inferior da Formação Barreiras apresenta falhas distensionais planares com mergulhos de alto a baixo ângulo, dominantemente para oeste, em arranjo dominó. $\mathrm{O}$ acamamento encontra-se basculado para SE, sem apresentar variação na espessura das camadas, sugerindo que as falhas são pós-deposicionais em relação à fácies inferior daquela formação. Este padrão também pode ser explicado por distensão próxima a E-W/WNW, conforme indicado pela orientação das estrias nos planos de falhas; deste modo, o mesmo correlaciona-se ao evento princi- pal de distensão referido no parágrafo precedente.

Outra feição peculiar é a ocorrência de zonas de cisalhamento com uma trama $\mathrm{L}>\mathrm{S}$ desenvolvido por mecanismos de dissolução e precipitação, e morfologia sigmoidal análoga às de equivalentes dúcteis. Tais estruturas apresentam direção WNW-ESE e rejeito normal, definindo um evento deformacional distinto do anterior, mais jovem (as zonas de cisalhamento afetam as camadas superiores da Formação Barreiras, previamente basculadas), agora com direção de distensão aproximadamente $\mathrm{N}-\mathrm{S}$.

Na região de Vila Nova, próximo a Icapuí, a figura 7 ilustra uma seção estrutural onde é possível observar dobramentos na fácies inferior da Formação Barreiras, com estruturas anticlinais que ladeiam um graben central, preenchido pela fácies superior da Formação Barreiras. As dobras são suaves, simétricas ou, menos comumente, assimétricas (fraca vergência para $\mathrm{SE}$ ). Associados ao dobramento, são identificados planos de clivagem de dissolução com arranjo em leque, direção média NNE e mergulhos fortes (Fig. 7). Localmente, as rochas exibem uma trama que inclui uma "lineação de estiramento", desenvolvida por processos de dissolução e precipitação de quartzo e óxidos/hidróxidos de ferro, formando agregados ou concreções elipsoidais ou prismáticas, com forte caimento. Falhas inversas de alto ângulo, nos flancos das dobras, são identificadas em exposições a oeste desta seção, sugerindo um mecanismo de dobramento por deslizamento flexural. Essas feições contracionais estão restritas a este setor.

Na mesma localidade, a deposição da fácies superior da Formação Barreiras é controlada por estruturas de grabens pull-apart, delimitados por falhas e zonas de cisalhamento oblíquas (sinistrais + normais), com direção N-NE, caracterizando um evento deformacional distensional superposto (vide a porção central da seção representada na Fig. 7). Os arenitos da fácies superior

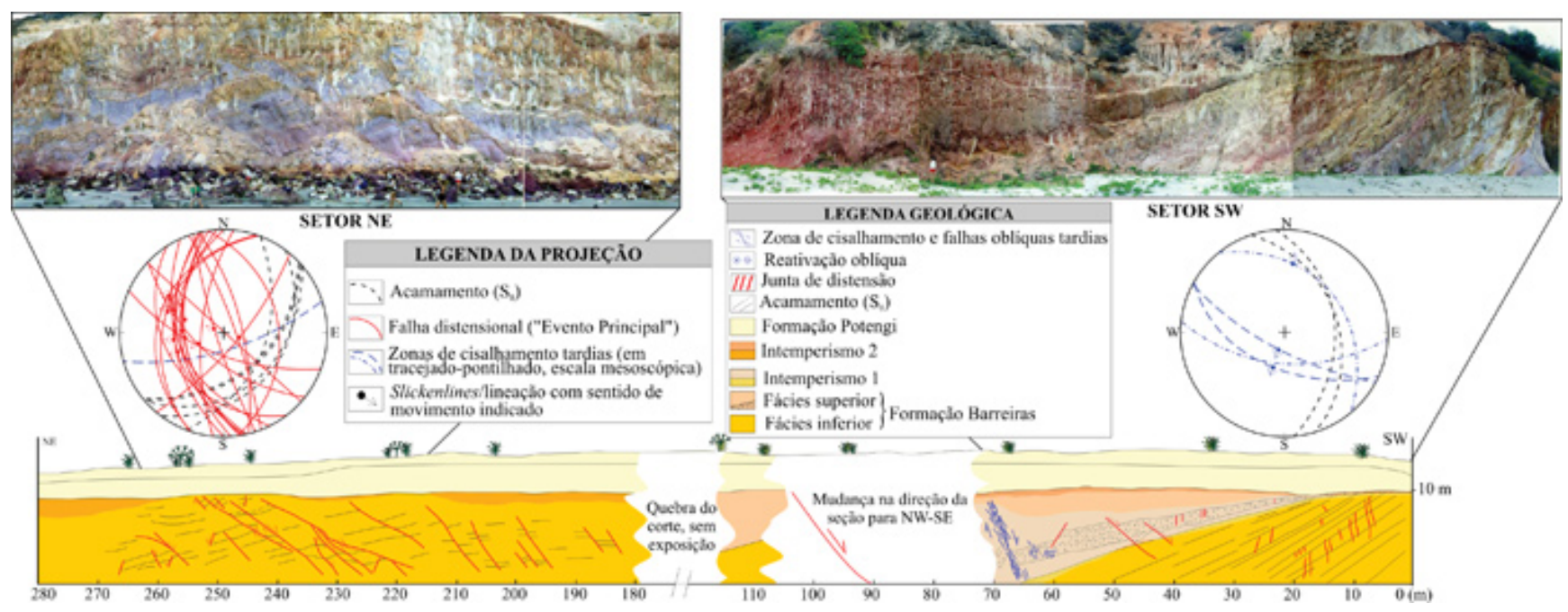

Figura 6 - Seção geológico-estrutural na localidade de Ponta Grossa. Os estereogramas ilustram os planos de falhas (observar a distinção entre as famílias/gerações representadas em vermelho e em azul) e do acamamento, bem como os slickenlines nas falhas. Localização da seção na figura 1. 


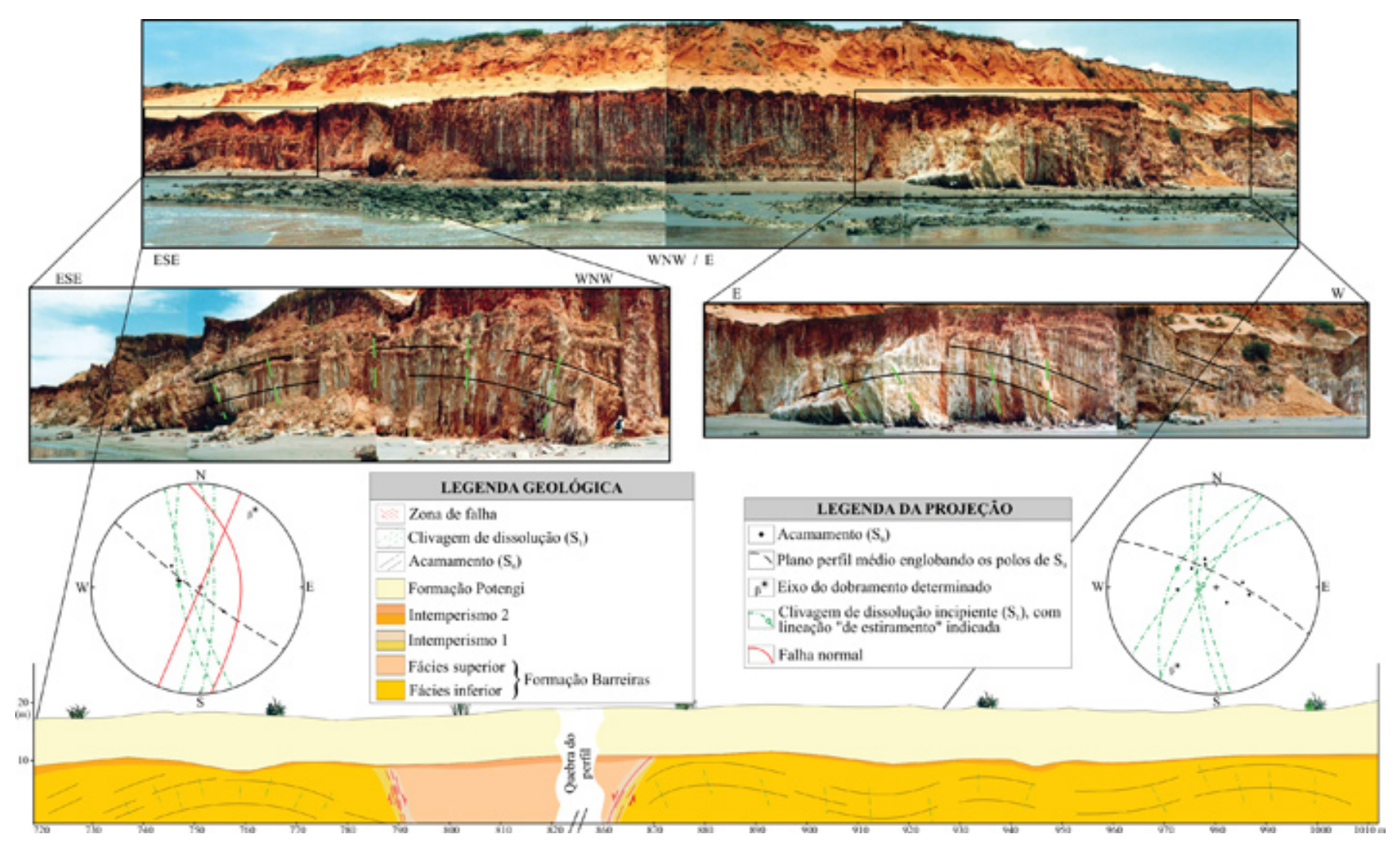

Figura 7 - Seção geológico-estrutural, na localidade de Vila Nova. Os estereogramas ilustram os planos do acamamento (nestes diagramas, representados pelos pólos), clivagem de dissolução, falhas e slickenlines. Localização da seção na figura 1 .

da Formação Barreiras são maciços, provavelmente por efeito de fluidização contemporânea à deformação. Os mesmos não exibem efeitos do dobramento que ocorre lateralmente, sugerindo que a deposição nos baixos estruturais foi tardia em relação ao evento contracional.

\section{INTERPRETAÇÃO DAS SEÇÕES SÍSMI-} CAS Com base na interpretação de seções sísmicas cedidas pela PETROBRAS, foi possível distinguir duas unidades em subsuperfície: (i) o embasamento cristalino pré-cambriano, cujo topo é marcado por refletores muito expressivos; sobre ele, ocorre (ii) a seção albiana-neocretácea da bacia, correspondendo às formações Açu (na base) e Jandaíra (no topo), fortemente afetadas por falhamentos.

Nas seções sísmicas (Fig. 8) foram evidenciados altos do embasamento cristalino, que se alinham segundo a direção NE-SW, interpretados como de origem primariamente topográfica - cristas de rochas miloníticas ou gnáissico-granitóides (marcadas por asterisco na Fig. 8), associadas às zonas de cisalhamento transcorrentes brasilianas, de trend NE (feição comum no embasamento desta região), exumadas pela erosão préalbiana. Tal interpretação coaduna-se com as observações de terreno a SW do Campo de Fazenda Belém, na Serra Dantas e no Serrote dos Porcos, onde o embasamento aflora como janelas no interior da bacia, orlados pelos calcários da Formação Jandaíra, incluindo níveis de conglomerados na base, ou pelas rochas siliciclás- ticas da Formação Açu. Em alguns trechos das seções sísmicas, os refletores na base da Formação Açu terminam em onlap sobre os altos de embasamento cristalino (indicado pelas setas vermelhas na Fig. 8), indicando que os mesmos constituíam, pelo menos parcialmente, feições paleotopográficas, quando da deposição dessa formação.

As seções sísmicas também evidenciam que o topo do embasamento cristalino/porção inferior da Formação Açu, e níveis estratigráficos superiores, já na Formação Jandaíra, estão seccionados por várias falhas, que podem coincidir com os altos topográficos ou seus flancos. Parte dessas falhas deve constituir reativações $\mathrm{da}(\mathrm{s})$ zona(s) de cisalhamento brasiliana(s) no embasamento, concentradas nos altos e suas bordas. Especialmente quando seccionam os altos do embasamento, as falhas são de alto ângulo e com aspecto ramificado (Fig. 8). Essas feições, associadas à presença de componentes de rejeito geralmente inversos, apresentam geometria semelhante à de estruturas-em-flor positivas (Figs. $8 \mathrm{e}$ 9), nas quais um componente importante de movimento direcional estaria presente. $\mathrm{O}$ estilo estrutural descrito é compatível com um regime de transpressão ao longo de zonas de falhas com trend NE, definindo o Lineamento Ponta Grossa-Fazenda Belém - LPGFB, o qual afeta as formações Açu e Jandaíra. Esse estilo contrasta com o regime distensional dominante, caracterizado na Formação Barreiras em Ponta Grossa, embora possa ser comparado (embora não necessariamente cronocorrela- 

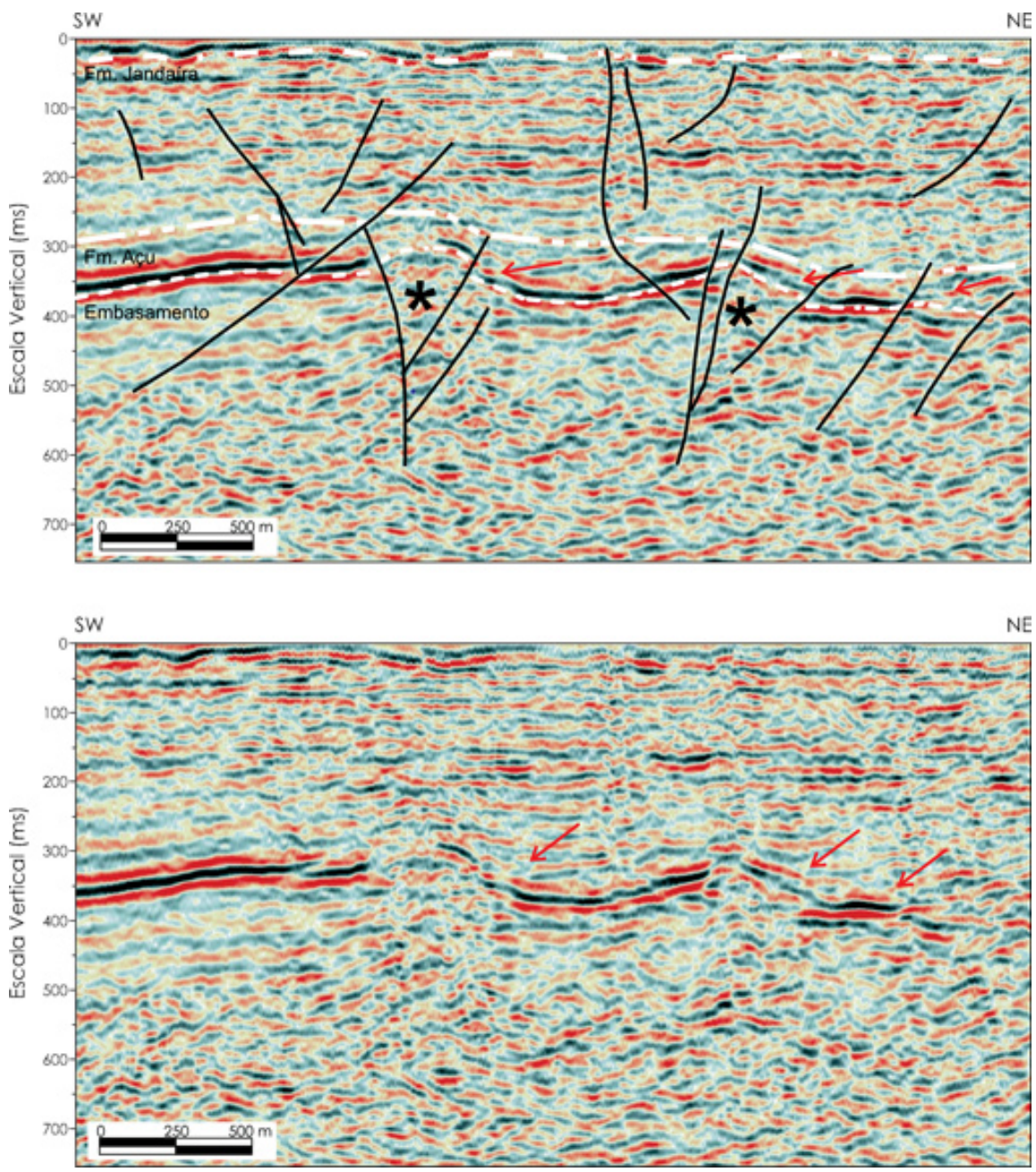

Figura 8 - Parte da seção sísmica S1 ilustrando a interpretação de estruturas-em-flor positivas e possíveis falhas com componente de rejeito direcional. Os asteriscos sinalizam altos do embasamento, interpretados como feições originalmente paleotopográficas, reativados pelas falhas. As setas indicam as terminações em onlap dos refletores da base da Formação Açu, sobre o embasamento.

to) às estruturas contracionais/transcorrentes nas falésias de Vila Nova.

No mapa do topo do embasamento, obtido a partir da interpolação das seções sísmicas (Sousa 2003), observa-se que as estruturas interpretadas têm direção $\mathrm{NE}$, com a ressalva do pequeno número de seções estudadas. Neste setor da Bacia Potiguar, a direção NE corresponde a um persistente lineamento, designado de Lineamento Ponta Grossa - Fazenda Belém, o LPGFB (Sousa 2003). A sua direção coincide com as estruturas transpressionais precoces observadas na Formação Barreiras, em Vila Nova. Por outro lado, as falhas distensionais N-S, em Ponta Grossa, parecem definir uma terminação ou ponte em transtração, que para este lineamento identificariam um componente direcional sinistral, ativo durante a deposição da referida formação.

Em direção ao topo nas seções sísmicas, as falhas interpretadas se tornam menores e passam a dominar componentes de rejeito normal. A dualidade de rejeitos (normal vs. inverso) em diferentes níveis estratigráficos sugere uma inversão na cinemática das falhas e do próprio contexto tectônico, com transpressão seguida por transtração. Numa escala regional, esses eventos podem ser enquadrados no contexto tectônico da Margem Equatorial e do interior continental adjacente, em correlação aos dados na literatura (Azevedo 1991, Matos 2000, Jardim de Sá 2001). O regime transpressivo, inferido a partir das estruturas que afetam as formações Açu e Jandaíra, no nível inferior das seções sísmicas de Ponta Grossa, deve ter sido ativo durante o Cretáceo Superior, pelo menos até o Paleógeno. O regime de transtração, com feições transpressivas mais localizadas (p.ex., em Vila Nova), foi ativo durante a deposição da Formação Barreiras. Recentes datações geocronológicas, pelos métodos ${ }^{39} \mathrm{Ar}-{ }^{40} \mathrm{Ar}$ em rochas vulcânicas sotopostas (Formação Macau) e óxidos de $\mathrm{Mn}$, e U-Th/He em óxidos/hidróxidos de Fe autigênicos e detríticos, permitem fixar uma idade mesomiocênica 


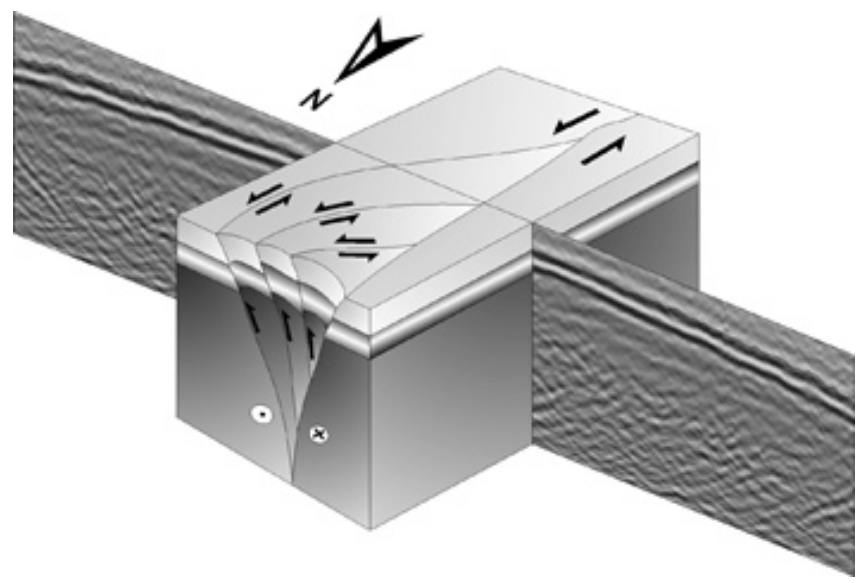

Figura 9 - Bloco diagrama esquemático ilustrando uma estrutura-em-flor positiva, com componentes inversos associados à movimentação transcorrente.

para a Formação Barreiras, no Rio Grande do Norte e Ceará (Jardim de Sá et al. 2005; Lima et al. 2007), sendo esta um limite máximo para o evento de transtração sinistral caracterizado no presente trabalho.

MODELO ESTRUTURAL E EVOLUÇÃO TECTÔNICA As feições descritas ressaltam a ocorrência de estruturas distensionais complexas e a deformação de grande magnitude ao longo da costa, afetando a Formação Barreiras. A extensão desta estruturação em profundidade e para o interior do continente, afetando diferentes unidades litoestratigráficas, somada a variações no seu estilo, orientação e cinemática, denotam a existência (ou mesmo a coexistência) de diferentes sistemas de tensões atuando no decorrer do tempo geológico, desde o Pré-cambriano até o Recente. Também deve ser destacado o papel do Lineamento Ponta Grossa-Fazenda Belém na evolução tectônica deste setor da Bacia Potiguar.

A interpretação das seções sísmicas sugere a ocorrência de altos do embasamento cristalino, com direção NE, originalmente associados a cristas de milonitos e granitóides ao longo de uma zona de cisalhamento brasiliana (Fig. 10a). Regionalmente, as transcorrências brasilianas com trend NE funcionaram em regime dextral (ou transpressivo dextral) durante aquele evento; com a exumação do terreno subseqüente à orogênese, reativações em temperaturas mais baixas (inclusive frágeis) mantiveram a mesma cinemática (Jardim de Sá 1994; Vauchez et al. 1995).

Durante o Cretáceo Inferior, o rifteamento no interior e margem continental do Nordeste obedeceu a uma evolução complexa, polifásica (Matos 1999, 2000). Para a região em questão, o estágio sinrifte incluiu a deposição da Formação Pendência no graben Potiguar, durante o Neocomiano. Este evento deve ter reativado falhas ao longo do LPGFB, com cinemática normal/distensional; por simplificação e pela falta de registro direto e marcadores na área discutida, este estágio evolutivo não foi representado na figura 10 .

A partir do Barremiano superior ao Aptiano, a abertura da Margem Equatorial Atlântica, em regime transcorrente/transformante dextral (Zalan et al. 1985, Azevedo 1991, Matos 2000), gerou falhas principais com direção E-W ou NW e foi acompanhada pela deposição das formações Pescada e Alagamar, no setor offshore da bacia. As formações Açu e Jandaíra foram depositadas na etapa subseqüente de subsidência termal (estágio drifte), entre o Albiano e o Santoniano. A deposição da Formação Açu foi influenciada pelos altos topográficos já desenvolvidos no embasamento (Fig. $10 \mathrm{~b}, \mathrm{c}$ ), os quais são localmente capeados diretamente pela Formação Jandaíra, com finos horizontes conglomeráticos na base.

No intervalo de tempo Barremiano superior ao Albiano, e provavelmente até o final do Cretáceo, o rifteamento oblíquo e a deformação subseqüente neste setor da Margem Equatorial (bacias Potiguar e do Ceará) passaram a ser condicionados por contração NW e distensão NE (Fig. 10c). Falhas E-W deformaram a plataforma e adentraram no continente (Azevedo 1991, Matos 2000, Costa et al. 2002). Este regime cinemático deve ter reativado estruturas pré-existentes, como o LPGFB, com cinemática contracional/transpressional sinistral (estruturas de alto ângulo, antitéticas em relação ao movimento E-W dextral na margem). Nesse contexto, a reativação poderia desenvolver as estruturas-em-flor positivas, observadas ao longo do LPGFB (Fig. 10c). As estruturas impressas nas formações Açu e Jandaíra, e no embasamento cristalino subjacente, devem ter sido desenvolvidas durante o Cretáceo Superior, até o Paleógeno (Fig. 10c).

Na Margem Equatorial, ou em setores da mesma, o regime transcorrente E-W, simplificadamente designado de "Regime Equatorial", continuou a operar durante o Neógeno. As dobras com trend NE na fácies inferior da Formação Barreiras, e estruturas-em-flor positivas, descritas na seção de Vila Nova, podem ter sido desenvolvidas neste regime cinemático.

Durante o Neógeno (Mioceno-Plioceno) e o início do Pleistoceno, é constatada a impressão de outro regime tectônico. A deformação distensional entre Ponta Grossa e Vila Nova, caracterizada por falhas normais com direção média N-S/NNE (eixo X/ $\sigma_{3} \mathrm{E}-\mathrm{W} / \mathrm{WNW}$ ). Esse estilo deformacional foi associado a um regime de transtração sinistral ao longo do LPGFB, e estaria especialmente desenvolvido em um sítio (terminação, jog) de transtração nessa zona de falha. Este regime deformacional contrasta com as direções associadas ao "Regime Equatorial" acima referido, bem como ao sistema de compressão E-W que caracteriza amplas regiões no interior da Placa Sul-Americana (Ferreira et al. 1998, Assumpção 1998, Lima et al. 1997, Lima 1999, Lima Neto 1998). A distensão E-W faz parte de um contexto interpretado como o soerguimento dômico do Planalto da Borborema, resultando em um campo de tensões mais localizado a esta região da placa (Jardim de Sá et al. 1999, Dantas et al. 1999). 
(a)
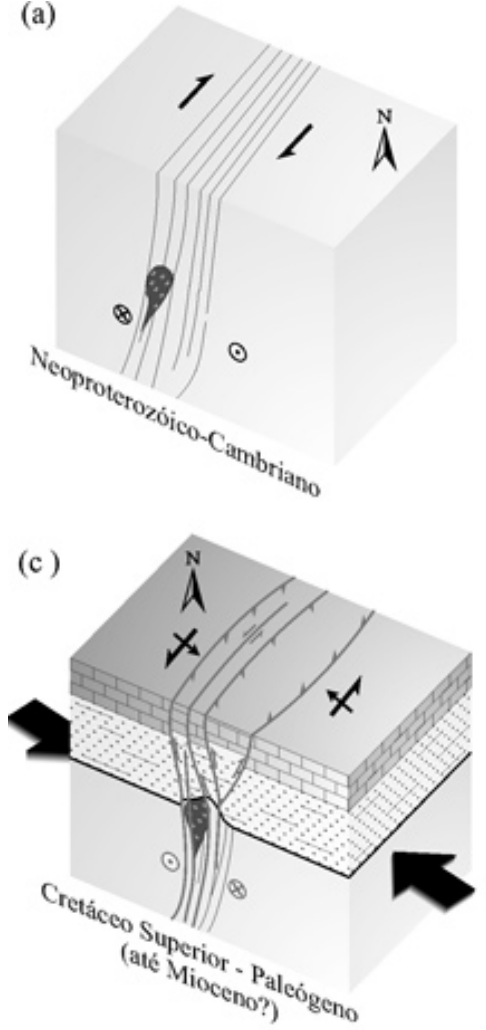

Legenda: (b)
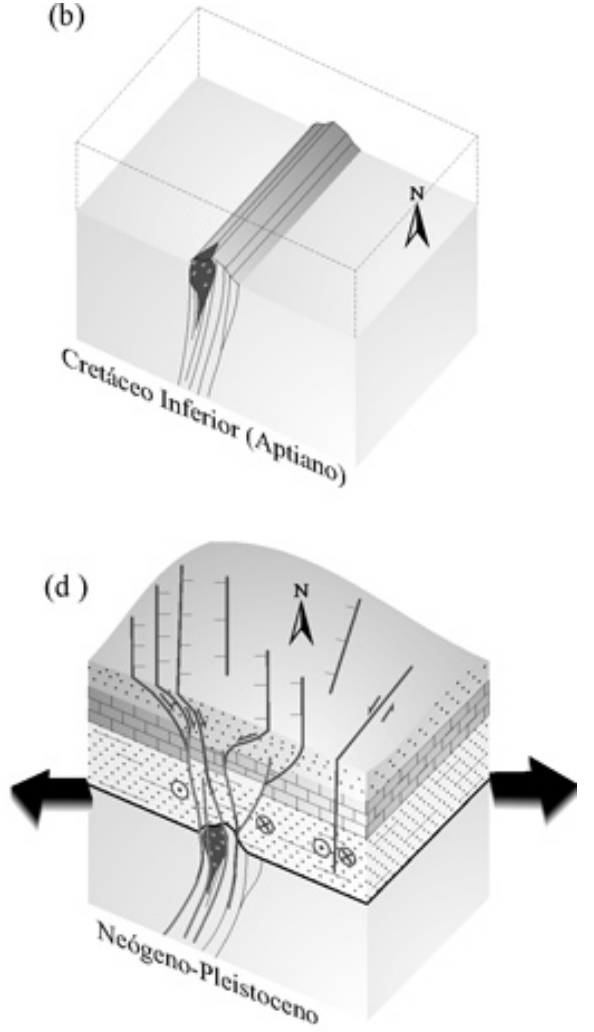

\footnotetext{
$::::$ Formação Barreiras

Formação Jandaíra

Formação Açu

Substrato gnáissico-migmatítico
}

Figura 10 - Modelo de evolução tectônica ilustrando a variação do campo de tensões e eixos cinemáticos, as estruturas observadas em superficie e sua correlação com as estruturas em maior profundidade.

DISCUSSÕES: IMPLICAÇÕES PARA A EXPLORAÇÃO E A EXPLOTAÇÃO DE PETRÓLEO No Brasil, a Bacia Potiguar ocupa a liderança na produção de hidrocarbonetos em terra, e o segundo lugar na produção em mar. Essa produção é proveniente de rochas geradoras e reservatórios, predominantemente siliciclásticos, distribuídos nas seqüências deposicionais relacionadas aos estágios rifte e drifte. Neste último, o óleo pode estar condicionado por trapas estruturais, mistas (estruturais e estratigráficas) ou paleogeomórficas (Bertani et al. 1990). Ainda na seção drifte, o óleo ocorre principalmente nos arenitos porosos e permeáveis da Formação Açu, em geral possuindo forte controle estrutural condicionado principalmente por grandes falhas, a exemplo das falhas de Carnaubais e Areia Branca, que têm direção preferencial NE-SW (Fig. 11).

$\mathrm{Na}$ área estudada, os campos da Fazenda Belém e de Icapuí (representados por FZB e IC na Fig. 11) têm como reservatórios os arenitos e conglomerados da base da Formação Açu (unidade designada informalmente de Açu-1). O Campo da Fazenda Belém coincide com um importante lineamento de trend NE-SW, o Lineamento Ponta Grossa-Fazenda Belém (LPGFB) (Sousa 2003), constituindo, segundo Bertani et al. (1990), um exemplo de trapa paleogeomórfica, com acumulações condicionadas pelos flancos dos paleoaltos do embasamento cristalino.

A análise geoquímica dos óleos da Formação Açu indica que sua geração ocorreu nos folhelhos negros, contendo intervalos ricos em matéria orgânica, da Formação Alagamar, que ocorrem na porção offshore da bacia (Santos Neto et al. 1990, Trindade et al. 1992, Souto Filho et al. 2000).

Em reservatórios situados no setor onshore da bacia, como no presente caso, a presença do óleo gerado offshore implica em migração lateral da ordem de algumas dezenas de quilômetros (Santos Neto et al. 1990, Trindade et al. 1992, Souto Filho et al. 2000), o que demanda a existência de condutos e trapas que possibilitem a acumulação de óleo nesse tipo de reservatório. É muito provável que o LPGFB desempenhe um papel de controle nessa compartimentação. É reportada uma grande complexidade na distribuição das fácies/zonas da Formação Açu neste setor, em parte creditada à influência dos paleoaltos topográficos, em parte ao próprio modelo deposicional (fluvial entrelaçado) da zona de interesse.

Tendo em vista as feições deformacionais reconhecidas em afloramento e em seções sísmicas, é neces- 


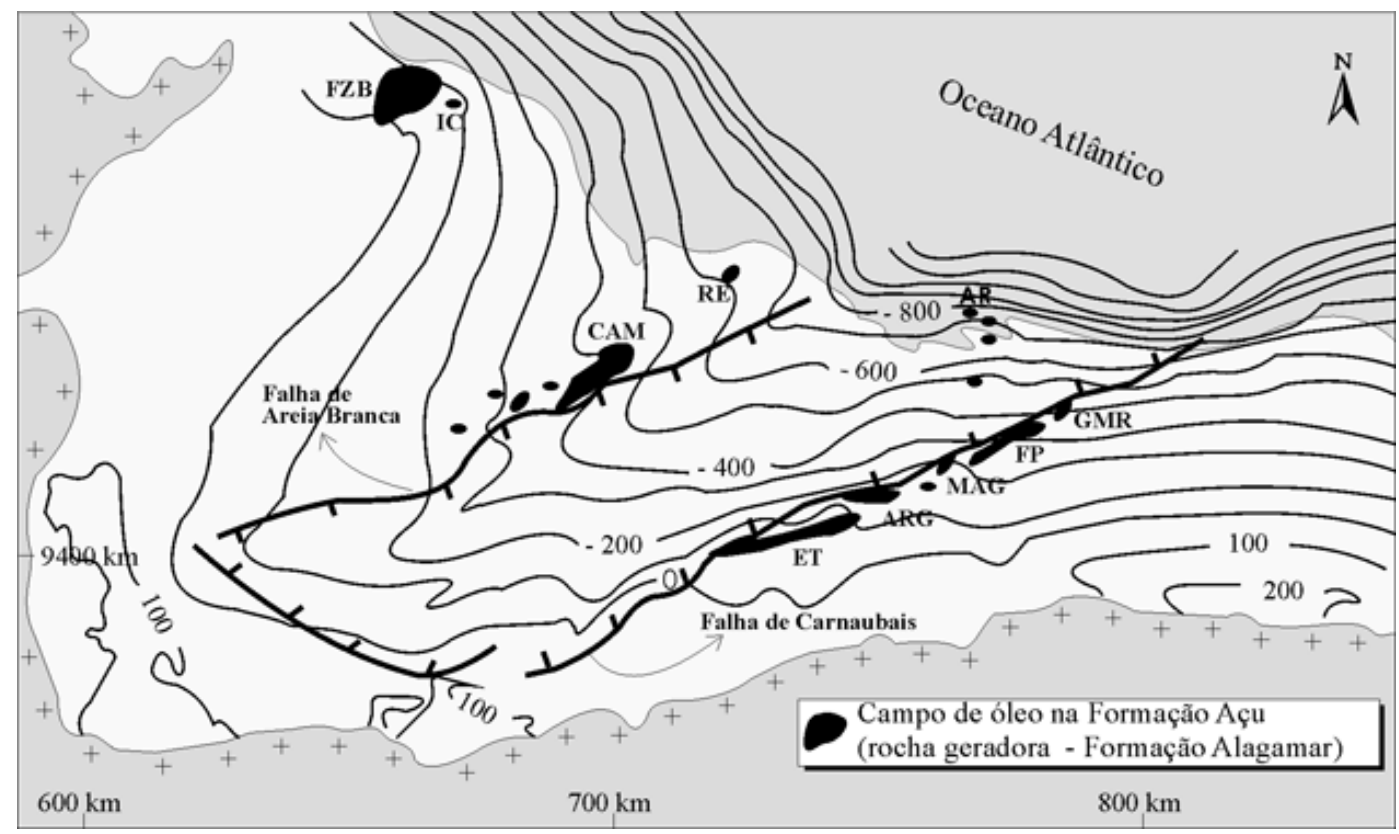

Figura 11 - Mapa de contorno estrutural do topo da Formação Açu, com a distribuição dos campos de óleo na referida formação (porção onshore da Bacia Potiguar). Modificado de Bertani et al. (1990) e Vasconcelos et al. (1990). Campos: FZB-Fazenda Belém, IC-Icapuí, CAM- Canto do Amaro, RE-Redonda, AR-Aratum, GMR Guamaré, FP-Fazenda Pocinho, MAG-Monte Alegre, ARG-Alto do Rodrigues e ET-Estreito.

sário discutir o papel desse estilo estrutural na formação e na conformação do Campo de Fazenda Belém, localizado sobre uma zona de falha reativada como transcorrência sinistral em pelo menos duas etapas, desde a deposição das rochas-reservatório da Formação Açu até a deposição e deformação da Formação Barreiras. O regime principal, acionado pela cinemática transcorrente/transformante da Margem Equatorial (Matos, 1999, 2000), esteve ativo durante o Cretáceo Superior e/ou o Terciário, conforme indicado pelas estruturas que afetam, em afloramento ou seções sísmicas, as rochas sedimentares aflorantes da bacia. Reativações ou nucleação de falhas transcorrentes E-W em arenitos de praia (Caldas et al. 1997), conduzem à interpretação de que o mesmo continuou ativo até o Holoceno. Interposto a este, tem-se o registro de um evento de domeamento e distensão geral na crosta superior, no intervalo Neógeno-Pleistoceno, levando à reativação transtracional do LPGFB, tendo associado um enxame de falhas oblíquas e normais.

Durante a deformação, as estruturas mapeadas em superfície necessariamente se propagam em profundidade. Nesse contexto, uma parte significativa da complexidade do Campo de Fazenda Belém pode ser de natureza estrutural. O movimento das falhas pode justapor, lateral e/ou verticalmente, blocos da Formação Açu com porosidades distintas, condicionando rotas de migração em menor escala, gerando e/ou destruindo trapas. Essa possibilidade deve ser considerada ao mesmo nível de prioridade da hipótese de controle do reservatório pela geometria de canais, níveis selantes e outras feições sedimentares. No mesmo sentido, a interpretação das se- ções sísmicas indica que os paleoaltos do embasamento tiveram a sua geometria modificada e amplificada por estruturas-em-flor positivas, configurando trapas do tipo combinadas (paleogeomórficas + estruturais).

A permoporosidade das falhas depende do estilo de deformação e das litologias justapostas, com resultado final freqüentemente apresentando balanço positivo, por facilitar o fluxo de fluidos (fato notório nos afloramentos da Formação Barreiras, caracterizados por cores variegadas que são produto de oxidação, descoloração e precipitação devido à percolação de fases fluidas). Por outro lado, o maior conteúdo de argilominerais e a freqüência de camadas ou lentes de sedimentos finos na Formação Barreiras favorecem a formação de espelhos argilosos, que exibem feições "miloníticas", hidroplásticas; esses casos tendem a produzir estruturas seladas. Na Formação Jandaíra, as falhas são comumente preenchidas por precipitados carbonáticos, que encontraram espaços abertos durante sua precipitação. Nos arenitos da Formação Açu, falhas e bandas de deformação desenvolvem uma matriz cominuída, inicialmente aumentando a permoporosidade; posteriormente, a precipitação de soluções ricas em sílica tende a desenvolver estruturas seladas (Antonellini \& Aydin 1995, Aydin 2000).

Modelagens realizadas por Souto Filho (1994) e Souto Filho et al. (2000) demonstram que, para a unidade Açu-3, decorridos 5 milhões de anos do início da migração a partir da Formação Alagamar (cujo pico do evento é estimado na passagem do Oligoceno para o Mioceno), o padrão de fluxo reconhece claramente o 
papel das descontinuidades NE (sistemas de falhas de Carnaubais e de Areia Branca; Fig. 12) como rotas preferenciais para avanço da frente de óleo, o que também é sugerido pela modelagem da migração de óleo na unidade Açu-1 (Fig. 12). A frente de migração avança para o continente, no setor entre Icapuí e Ponta Grossa, coincidindo com a localização do LPGFB. Considerando a sua idade tardia em relação à bacia, a migração do óleo aproveitou a declividade do topo do embasamento e as descontinuidades pré-existentes (as grandes estruturas cretáceas), devendo, porém, ter sido controlada ou influenciada, em maior detalhe, pelo regime tectônico atuante durante o Neógeno.

CONCLUSÕES Os estudos realizados ao longo do litoral cearense, entre as localidades de Lagoa do Mato e Icapuí, no extremo noroeste da Bacia Potiguar, destacam o forte basculamento das camadas da Formação Barreiras, relacionado a uma deformação distensional de forte magnitude, incomum em seqüência tão jovem. Arranjos complexos de falhas distensionais em dominó, com zonas de descolamento, também traduzem a magnitude deste evento deformacional. Em adição, a Formação Barreiras também exibe dobras e estruturas
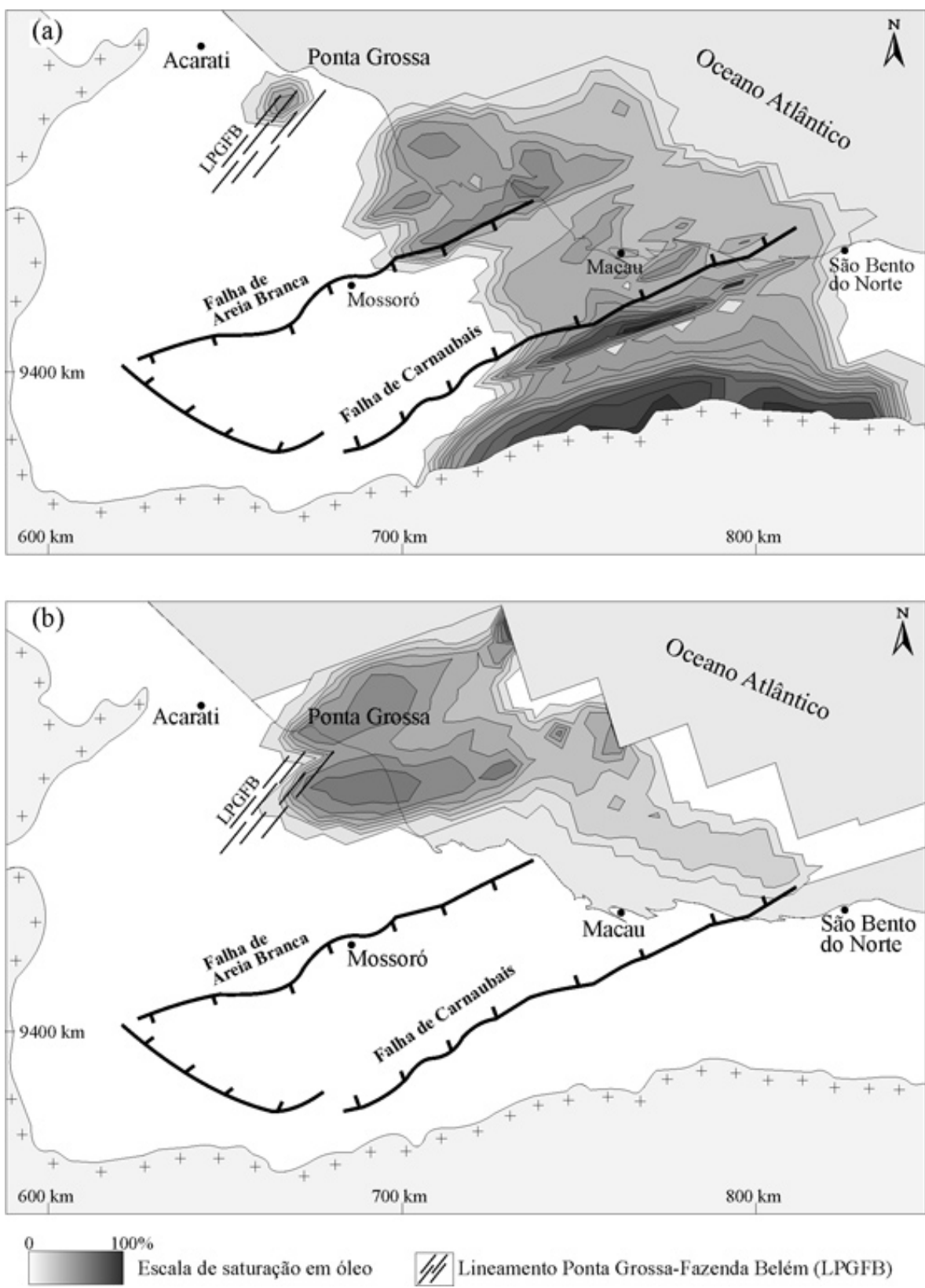

Figura 12 - Mapas de saturação de óleo (Souto Filho, 1994) em duas situações: (a) para a unidade Açu 3, em 5 milhões de anos após início da migração secundária e (b) para a unidade Açu 1, em 2 milhões de anos após o início da migração secundária. Nos dois mapas estão inseridas as principais falhas do arcabouço estrutural, bem como o LPGFB. 
transpressionais bem desenvolvidas, na localidade de Vila Nova. A distribuição geográfica dos setores estruturais reconhecidos envolve uma coincidência com lineamentos brasilianos e zonas de falhas NE, sendo que estas últimas parecem controlar o campo de petróleo da Fazenda Belém, na borda ocidental da Bacia Potiguar.

Considerando a deformação distensional, os afloramentos entre as localidades de Ponta Grossa e Redonda oferecem uma oportunidade ímpar para documentar vários estilos estruturais que, no país, em geral são conhecidos principalmente através de seções sísmicas nas bacias costeiras.

As estruturas contracionais observadas na localidade de Vila Nova afetam a fácies inferior da Formação Barreiras, com dobras bem desenvolvidas, às quais associa-se uma trama $\mathrm{S}>\mathrm{L}$ incipiente, gerada por mecanismos de dissolução, concentração residual e precipitação. Uma inversão negativa é documentada pela superposição de falhas oblíquas, delimitando estruturas de graben pull-apart preenchidos pela fácies superior da Formação Barreiras.

Tais estruturas estão particionadas geograficamente entre dois setores do Lineamento Ponta GrossaFazenda Belém (LPGFB, com trend NE), caracterizando sítios e regimes em transpressão ou transtração, por sua vez conectados com estruturas transcorrentes E-W, ao longo da Margem Equatorial. Essas estruturas foram geradas por eventos cuja idade abrange o limite Neógeno-Pleistoceno.

A forte deformação caracterizada na Formação Barreiras, em um nível muito raso na crosta, deve ser compatibilizada com as estruturas que afetam as rochas em profundidade. Assim, a estruturação identificada nas formações Açu e Jandaíra, antes creditada principalmente a um evento neocretáceo, provavelmente contém uma contribuição considerável dessa atividade neógena, o que levanta várias implicações no tocante à exploração e/ou explotação de óleo neste setor da Bacia Potiguar.

$\mathrm{O}$ modelo estrutural proposto para integrar as feições observadas em superfície com aquelas de subsuperfície está associado a dois regimes tectônicos: (i) a deformação transcorrente dextral da Margem Equatorial, associada com terminações em transpressão de zonas $\mathrm{E}-\mathrm{W}$ ou zonas NE transpressionais antitéticas, sinistrais (a exemplo do LPGFB), funcionando intermitentemente desde o final do Cretáceo; (ii) uma etapa transtracional neógena-pleistocênica, associada aos processos de vulcanismo (Macau, Messejana) e domeamento térmico, na qual o LPGFB continuou a funcionar com cinemática sinistral.

Em síntese, e como uma das principais contribuições deste trabalho, constata-se que a estruturação do Campo de Fazenda Belém, e possivelmente de outros na Bacia Potiguar, deve ter sido significativamente alterada (ou construída) em época relativamente jovem, a partir do Mioceno, em um evento que coincide no tempo com a etapa principal de geração e migração de óleo na bacia.

Agradecimentos Os autores agradecem ao Programa de Pós-Graduação em Geodinâmica e Geofísica da Universidade Federal do Rio Grande do Norte (PPGG/ UFRN) pelo apoio na realização do trabalho, a ANP (Agência Nacional do Petróleo), por meio do Programa de Recursos Humanos (PRH-22), a PETROBRAS UN $\mathrm{RN}-\mathrm{CE}$ e ao CNPq/Proset/CTPetro. Várias discussões de colegas do PPGG e da PETROBRAS contribuíram para enriquecer o tema, com especial agradecimento ao apoio dado pelo Dr. Renato Marcos Darros de Matos. Finalmente, os autores agradecem ao revisor anônimo, cujas observações resultaram em sensível melhora do texto.

\section{Referências}

Antonellini M. \& Aydin A. 1995. Effect of faulting on fluid flow in porous sandstones: geometry and spatial distribuition. AAPG Bulletin, 79:642-671.

Assumpção M. 1998. Seismicity and stress in the Brazilian passive margin. Bull.Seismol.Soc. America, 88:160-169.

Aydin A. 2000. Fractures, faults and hydrocarbon entrapment, migration and flow. Marine and Petroleum Geol., 17:797-814.

Azevedo R.P. 1991. Tectonic evolution of brazilian equatorial continental margin basins. Tese de Doutoramento, University of London, Imperial College, London, 455p.

Bertani R.T., Costa I.G., Matos R.M.D. 1990. Evolução Tectono-sedimentar, Estilo Estrutural e o Habitat do Petróleo na Bacia Potiguar. In: Raja Gabaglia G.P. \& Milani E.J. (eds.). Origem e Evolução de Bacias Sedimentares. Petrobras, p.291-310.

Bezerra F.H.R., Lima Filho F.P., Amaral R.F., Caldas L.H.O., Costa Neto L.X. 1998. Using beachrocks and hydroisostatic predictions to identify Holocene coastal tectonics in NE Brazil. In: Stewart I.S. \& Vita-Finzi C. (eds.). Coastal Tectonics. Geological Society Special Publica- tion, 146:279-293

Bezerra F.H.R. \& Vita-Finzi C. 2000. How active is a passive margin? Paleoseismicity in northeastern Brazil. Geology, 28:591-594.

Bezerra F.H.R., Mello C.L., Suguio K. 2006. A Formação Barreiras: recentes avanços e antigas questões. Geologia USP Série Cientifica, 6(2):iii-vi.

Caldas L.H.O., Coriolano A.C.F., Dantas E.P., Jardim de Sá E.F. 1997. Os beachrocks no litoral do Rio Grande do Norte: potencial como marcadores neotectônicos. In: SBG/Núcleo Nordeste, Simp. Geol. NE, 17, Fortaleza, Boletim Resumos, 15, p.369-376.

Costa P.R.C., Antunes A.F., Jardim de Sá E.F, Amaro V.E., Matos R.M.D. 2002. O registro da deformação Mesozóica relacionada à abertura da Margem Equatorial Atlântica no litoral do Estado do Ceará (NE do Brasil): Evidências a partir da análise de imagens orbitais e de afloramentos. In: SBG/Núcleo Nordeste, Cong. Bras. Geol., 41, João Pessoa, Anais, p.623-623.

Dantas E.P, Jardim de Sá E.F., Castro D.L. 1999. Análise de lineamentos na porção central da Bacia Potiguar, e sua 
reativação neotectônica. In: SBG/Núcleo Bahia-Sergipe, Simp. Nac. de Estudos Tectônicos, 7, Lençóis, atas, p.86-89.

Ferreira J.M., Oliveira R.T., Takeya M.K., Assumpção M. 1998. Superposition of local and regional stresses in northeast Brazil: evidence from focal mechanisms the Potiguar Marginal Basin. Geophys. J. Int., 134:341-355.

Furrier M., Araújo M.E., Meneses L.F. 2006. Geomorfologia e tectônica da Formação Barreiras no Estado da Paraíba. Geologia USP Série Cientifica, 6(2):61-70.

Jardim de Sá E.F. 1994. A Faixa Seridó (Província Borborema, NE do Brasil) e seu significado geodinâmico na Cadeia Brasiliana/Pan-Africana. Tese de Doutoramento, Instit. Geociências, Universidade de Brasília, 803p.

Jardim de Sá E.F. 2001. Tectônica cenozóica na margem equatorial da Província Borborema, Nordeste do Brasil (A contribuição da Geologia Estrutural no continente). In: SBG/Núcleo Nordeste, Simp. Nac.de Estudos Tectônicos, 8, Recife, atas, p. 25-28.

Jardim de Sá E.F., Matos R.M.D., Morais Neto J.M., Saadi A. 1999. Epirogenia cenozóica na Província Borborema: síntese e discussão sobre os modelos de deformação associados. In: SBG/Núcleo Bahia-Sergipe, Simp. Nac. de Estudos Tectônicos, 7, Lençóis, atas, p.58-61.

Jardim de Sá E.F., Souza Z.S., Vasconcelos P.M.P., Saadi A., Galindo A.C., Lima M.G., Oliveira M.J.R. 2005. Marcos temporais para a evolução cenozóica do Planalto da Borborema. In: SBG/Núcleo Paraná, Simp. Nac. de Estudos Tectônicos, 10, Curitiba, atas, p.160-162.

Lima Neto F.F. 1998. O exemplo da interferência mecânica de uma interface fraca: o campo atual de tensões na Bacia Potiguar. Dissertação de Mestrado, Universidade Federal de Ouro Preto, Ouro Preto, 320p.

Lima C.C. 1999. Expressions topographiques et structurales de l'etat de compression generalisee au sein de la Plaque Sud-Americane. Tese de Doutoramento, L'Université de Rennes 1, 124p.

Lima C.C., Nascimento E., Assumpção M. 1997. Stress orientations in Brazilian sedimentary basins from breakout analysis: implications for force models in the South American plate. Geophys. Jour. Intern., 130:112-124.

Lima C.C.U., Vilas Boas G.S., Bezerra F.H.R. 2006. Faciologia e análise tectônica preliminar da Formação Barreiras no litoral sul do Estado da Bahia, Brasil. Geologia USP Série Cientifica, 6(2):71-80.

Lima M.G., Vasconcelos P., Farley K., Jardim de Sá E.F. 2007. Datação do intemperismo impõe limites na idade da Formação Barreiras, Bacia Potiguar Nordeste do Brasil. In: Congresso da ABEQUA, 10, Belém/PA, atas, CD-Room.

Matos R.M.D. 1999. History of the northeast Brazilian rift system: kinematic implications for the break-up between Brazil and West Africa. In: Cameron N.R., Bate R.H. \& Clure V.S. (eds.) The Oil and Gas Habitats of the South Atlantic. Geological Society, London, Special Publications, 153:55-73.
Matos R.M.D. 2000. Tectonic Evolution of the Equatorial South Atlantic. In: Mohriak W \& Talwani M. (eds.) Atlantic Rifts and Continental Margins. Geophysical Monograph, 115:331-354.

Nogueira F.C.C., Bezerra F.H.R., Castro D.L. 2006. Deformação rúptil em depósitos da Formação Barreiras na porção leste da Bacia Potiguar. Geologia USP Série Cientifica, 6(2):51-59.

Santos Neto E.V., Mello M.R., Rodrigues R. 1990. Caracterização geoquímica dos óleos da Bacia Potiguar. In: SBG/ Núcleo Nordeste, Cong. Bras. Geol., 36, Natal, Anais, 2:974-985.

Sousa D.C. 2003. Litoestratigrafia e deformação cenozóica na região de Icapuí, Ceará, e implicações para a estruturação de campos de petróleo na borda ocidental da Bacia Potiguar (NE do Brasil). Tese de Doutoramento Pós-Graduação em Geodinâmica e Geofísica, Universidade Federal do Rio Grande do Norte, Natal/RN, 189p.

Sousa D.C., Jardim de Sá E.F., Matos R.M.D. 2001. Caracterização da deformação na Formação Barreiras na região de Ponta Grossa (Icapuí, CE), litoral ocidental da Bacia Potiguar. In: SBG/Núcleo Nordeste, Simp. Nac. de Estudos Tectônicos, 8, Recife, atas, p.355-357.

Sousa D.C., Jardim de Sá E.F., Matos R.M.D., Oliveira D.C. 1999. Deformação sin- e pós-Formação Barreiras na região de Ponta Grossa (Icapuí/CE), litoral ocidental da Bacia Potiguar. In: SBG/Núcleo Bahia-Sergipe, Simp. Nac. de Estudos Tectônicos, 7, Lençóis, atas, p.90-93.

Souto Filho J.D. 1994. Utilização de simulador numérico na análise do processo de migração secundária de petróleo. Dissertação de Mestrado, UNICAMP, 164p.

Souto Filho J.D., Correa A.C.F., Santos Neto E.V., Trindade L.A.F. 2000. Alagamar-Açu petroleum system, onshore Potiguar Basin, Brazil: A numerical approach for secondary migration. In: Mello M.R. \& Katz B.J. (eds.) Petroleum systems of South Atlantic margins. AAPG Memoir 73:151-158.

Trindade L.A.F., Brassel S.C., Santos Neto E.V. 1992. Petroleum migration and mixing in the Potiguar Basin, Brazil. AAPG Bulletin, 76:1903-1924.

Vasconcelos E.P., Lima Neto F.F., Ross S. 1990. Unidades de Correlação da Formação Açu. In: SBG/Núcleo Nordeste, Cong. Bras. Geol., 36, Natal, Anais, 1:227-240.

Vauchez A., Neves S.P., Caby R., Corsini M., Egydio-Silva M., Arthaud M., Amaro V.E. 1995. The Borborema shear zone system, NE Brazil. J. South Amer. Earth Science., 8:247-266.

Zalán P.V., Nelson E.P., Warme J.E., Davis T.L. 1985. The Piauí Basin: rifting and wrenching in an Equatorial Atlantic transform basin. In: Biddle \& Blick (eds.) Strikeslip Deformation, Basin Formation and Sedimentation. Soc. Econ. Paleontologist and Mineralogist (SEPM), Spec. Publ., 37:177-192.

Manuscrito BR 22

Submetido em 19 de dezembro de 2007 Aceito em 30 de maio de 2008 